oświaty, wychowania i nauki, a także samych pedagogów (w tym i dydaktyków), i co do tego faktu nie ma najmniejszej wątpliwości. Recenzowana publikacja stanowi pozycję wyjściową, zachęcającą, a przede wszystkim prowokującą do dalszych dydaktycznych poszukiwań na przestrzeni dziejów. W przypadku rozwinięcia omawianej problematyki, Szkice z dziejów dydaktyki mogą okazać się pozycją niezwykle pomocną, będącą bazą wyjściową dla dalszych poszukiwań i bardziej szczegółowych poczynań badawczych. To wreszcie ciekawa prezentacja rozległości zainteresowań Autora zarówno dla wykładowców, jak i dla studentów, którym nie są obce jego wcześniejsze publikacje.

Konrad Nowak-Kluczyński

\title{
Na wygnanie do Tarnopola. Wspomnienia Jana Zamorskiego (1874-1948), oprac. J. Szablicka-Zak, Wyd. Goldruk, b.r. i m. w., SS. 115
}

Rola wspomnień i pamiętników dla badaczy przeszłości jest nie do przecenienia. Stanowią one bowiem bogate źródło informacji o minionych czasach, postrzeganych oczami jednostki. Relacje osobiste wymagają jednak osobliwego postępowania badawczego, narażonego na nadmierny subiektywizm, ale czyż każda proponowana wersja historii nie jest także wersją autorską? Są także owe wspomnienia często jedynym źródłem dla odtworzenia informacji, których próżno byłoby szukać np. w archiwach (np. kwestie dotyczące świadomości, mentalności etc.). W tym kontekście każda inicjatywa wydania i edycji czyichś wspomnień jest cenna.

Taką właśnie pozostaje aktywność Jolanty Szablickiej-Żak, wrocławskiej badaczki historii wychowania, która pokusiła się o wydanie zapisków Jana Zamorskiego (18741948), absolwenta Uniwersytetu Jagiellońskiego, profesora c.k. Wyższej Szkoły Realnej w Tarnopolu, działacza Towarzystwa Szkoły Ludowej i Towarzystwa Gimnastycznego „Sokół”, animatora czasopiśmiennictwa kresowego i, wreszcie, posła do parlamentu austriackiego, Sejmu Krajowego galicyjskiego i Sejmu w odrodzonej Rzeczypospolitej. Już sam ten wykaz funkcji przezeń sprawowanych sugeruje, iż Zamorski był postacią niezwykle interesującą, a jego osobiste cechy spowodowały, że także osobą niezwykle barwną i nawet $\mathrm{z}$ racji na poglądy - kontrowersyjną.

Książka, z racji na swój gatunek ma prostą konstrukcję. Zaczyna się od „Wstępu” i rozdziału, który pokrótce przedstawia sylwetkę Jana Zamorskiego i kreśli szkic Tarnopola. Miasto nie jest przypadkowe, gdyż właśnie tam umiejscowione są wydarzenia opisane przez Zamorskiego. W Tarnopolu bowiem zaczynał on swoją karierę jako nauczyciel. Treść zasadniczą pracy stanowią właśnie jego zapiski. Całość zamyka spis bibliografii, obejmujący nie tylko źródła, opracowania, ale także spis prac J. Zamorskiego.

Prezentowana książka jest ważna szczególnie dla środowiska historyków wychowania. Po pierwsze dlatego, że Zamorski jako praktykujący nauczyciel miał świadomość, że jego zapiski mają walory pedagogiczne. Problematyka związana z życiem szkoły jest bo- 
wiem najczęstszą w narracji. Po wtóre zaś, zapiski Zamorskiego są ilustracją życia w Tarnopolu, pokazują, jak to było być ,inteligencją z przełomu wieków”, pozbawioną własnego państwa, inteligencją z jej ambicjami, rozterkami i bolączkami. Tego nie znajdzie się w żadnych urzędowych dokumentach i sprawozdaniach, także z racji estetycznych, gdyż wspomnienia J. Zamorskiego napisane ładną i, czasami usianą żartami, polszczyzną, czyta się wyśmienicie. Wartościowe szczególnie są te fragmenty wspomnień, w których ich autor dzieli się swymi osobistymi wyznaniami, które dotyczyły przekonań moralnych i krystalizujących się zapatrywań politycznych młodego człowieka, który w ostro podzielonym ekonomicznie, socjalnie i kulturowo społeczeństwie kresowym poszukuje własnej drogi $i^{1}$. Jak byłyby one odebrane dzisiaj przez młodych ludzi, w czasach, gdy rzeczywistość nas otaczająca zmierza do jednolitości i globalizacji? Czy współczesna młodzież podzielałaby rozterki młodego ,prowincjonalnego” nauczyciela?

Będzie to możliwe do rozszyfrowania, gdy publikacja J. Szablickiej-Żak trafi pod strzechy i będzie czytana. Sama postać J. Zamorskiego powinna być zachętą, szczególnie z tego powodu, że wszystkim jego działaniom, tak rozległym, zawsze towarzyszyło coś, o czym i dzisiaj należy pamiętać: dobro Ojczyzny. Przy wszelkich zaś wynikających z tego powodu nieścisłościach i niedomówieniach należy pamiętać, iż kiedy na kartach historii dotykamy życia ludzkiego, wszelkie oceny winny podlegać weryfikacji².

Edyta Głowacka-Sobiech

\section{Aleksandra Siedlaczek-Szwed, Działalność opiekuńcza towa- rzystw dobroczynnych na Wileńszczyźnie w Drugiej Rzeczypospoli- tej, Wydawnictwo Akademii im. Jana Długosza w Częstochowie, Częstochowa 2009, ss. 288}

Dzieje opieki i pomocy społecznej na ziemiach polskich to tematyka, która wciąż nie cieszy się zbyt dużym zainteresowaniem badaczy. Stąd też szczególną wartość ma wydana w tym roku książka Aleksandry Siedlaczek-Szwed poświęcona międzywojennym towarzystwom dobroczynnym na Wileńszczyźnie. Publikacja ta jest kontynuacją zainteresowań autorki problematyką opieki na Kresach, które znalazły wyraz m.in. w jej książce Wileńskie Towarzystwo Opieki nad Dziećmi w latach 1901-1940 (Częstochowa 1998).

Praca, której głównym materiałem badawczym były artykuły prasowe oraz archiwalia, składa się z pięciu rozdziałów, a zagadnienia opieki z lat 1918-1939 przedstawione są w nich w sposób problemowy. Ponadto książka posiada obszerną bibliografię oraz kilkudziesięciostronicowy aneks, gdzie autorka prezentuje fragment materiału badawczego: wykaz towarzystw dobroczynnych, działających na Wileńszczyźnie w Drugiej Rzeczypospolitej oraz pięć przykładowych statutów takich organizacji.

\footnotetext{
Ibidem, s. 9.

2 Ibidem, s. 30.
} 